RESEARCH REPORT

\title{
Ethnic differences in cause specific mortality among hospitalised patients with diabetes: a linkage study in New Zealand
}

\author{
Mona Jeffreys, Craig Wright, Andrea 't Mannetje, Ken Huang, Neil Pearce
}

J Epidemiol Community Health 2005;59:961-966. doi: 10.1136/jech.2005.037515

See end of article for authors' affiliations

.....................

Correspondence to: Dr M Jeffreys, Centre for Public Health Research, Massey University, Private Bag 756, Wellington, New Zealand; m.jeffreys@ massey.ac.nz

Accepted for publication 26 June 2005

\begin{abstract}
Study objective: To describe patterns of excess mortality among patients with diabetes in three ethnic groups.

Design: A linkage study of national hospital discharge records to death records.

Setting: New Zealand.

Participants: The study included 74847 patients (1 1268 Māori, 5730 Pacific, and 57849 non-Māori/ non-Pacific) aged over 25 years with a hospital discharge diagnosis of diabetes between 1988 and 2001. By the end of 2001, 29295 (39\%) of the cohort had died. Based on the underlying cause of death, standardised mortality ratios (SMRs) (95\% confidence intervals) were calculated for each ethnic group and sex.

Main results: Comparing the mortality patterns of patients with diabetes to the general population of the same ethnic group, adjusting for age and calendar period, all cause SMRs were higher for Māori women and men: 3.80 (95\% Cl: 3.64 to 3.97 ) and 3.44 (95\% Cl: 3.30 to 3.58) than for Pacific (men: 2.41 (95\%Cl: 2.21 to 2.61); women: 2.23 (95\%Cl: 2.06 to 2.41)) and non-Māori/non-Pacific (men: 2.98 (95\% Cl: 2.93 to 3.04); women: 2.99 (95\% Cl: 2.93 to 3.04)) people. SMRs were significantly raised for several causes of death, including cardiovascular disease and many site specific cancers.

Conclusions: The pattern of excess mortality among Māori with diabetes may relate to severity of disease. This needs further investigation, as the excess mortality may be amenable to intervention.
\end{abstract}

M ortality rates among people with type 2 diabetes are higher than the general population. Estimates of the magnitude of this excess mortality vary widely, and although the differences are partially dependent on the sources of the diabetes cases, such selection factors do not seem to explain all of the reported differences in mortality. Studies that identify diabetes patients through primary and secondary care sources show slightly increased (25\% to 50\%) standardised mortality ratios (SMR), although other population based studies report SMRs or relative risks (RR) of about twice that of the general population. ${ }^{1-3}$ Studies based on patients with diabetes identified through hospital records report higher SMRs, ${ }^{4}$ presumably because of the selective inclusion of more severe cases of diabetes or patients with comorbidities. Basing diagnosis on insulin use in type 2 diabetes also results in high all cause SMRs. 5

Most previous reports examine broad categories of causes of death, and there is general consensus that excess mortality is evident for cardiovascular and renal disease. ${ }^{167}$ Cancer mortality may also be increased, ${ }^{48}$ although not all studies have found this ${ }^{167}$ and some studies have reported lower SMRs for cancer mortality in patients with diabetes. ${ }^{9}$ There are few reports that investigate site specific cancer mortality in patients with diabetes.

The prevalence of diabetes in New Zealand differs by ethnicity. A national survey of self reported doctor diagnosed diabetes found lowest rates in New Zealand Europeans (2.5\% in women and $3.1 \%$ in men), and higher rates in Māori $(9.8 \%$ in women and $8.0 \%$ in men) and Pacific people $(8.2 \%$ in women and $6.8 \%$ in men). ${ }^{10}$ These differing rates across ethnic groups are only partly explained by differing levels of obesity. ${ }^{11}$ The aim of this study was to describe cause specific mortality among patients admitted to a public hospital in
New Zealand, and to investigate whether these patterns differed by ethnicity.

\section{METHODS}

The study entailed linkage between electronic hospital discharge data and mortality data. Patients included in the study were New Zealand residents who were discharged from a public hospital with a code for diabetes mellitus, as recorded on the National Minimum Dataset (NMDS) between 1988 and 2001 and were aged 25 or over at the time of discharge. Note that the included patients may or may not have been diagnosed with diabetes before admission, but all had been diagnosed with diabetes at the time of discharge. The International Classification of Disease (ICD-9) codes used to define diabetes mellitus were 2500 to 2509. People were identified using the National Health Index (NHI) identifier, a number assigned to each person using health and disability support services. For people with multiple diabetes discharges, the first admission during the period 1988 to 2001 was used.

Ethnicity was assigned using the recorded ethnicity in the NHI database, prioritised using the Māori, Pacific, nonMāori/non-Pacific groups. ${ }^{12}$ The prioritised system minimises the possibility of undercounting Māori and Pacific people. The non-Māori/non-Pacific group is predominantly of European origin, although does include a significant proportion (about 7\%) of Asians.

The cohort of patients with a discharge summary including diabetes was linked to the national death registration data held by the New Zealand Health Information Service

Abbreviations: SMR, standardised mortality ratio; $\mathrm{RR}$, relative risk; $\mathrm{Cl}$, confidence interval; NMDS, National Minimum Dataset 
Table 1 Description of all patients aged 25 years or more discharged from New Zealand public hospital with diabetes, 1988 to 2001

\begin{tabular}{|c|c|c|c|c|c|c|c|c|}
\hline & \multicolumn{4}{|l|}{ Women } & \multicolumn{4}{|l|}{ Men } \\
\hline & number & median & range & p value & number & median & range & p value * \\
\hline \multicolumn{9}{|l|}{ Age at diabetes discharge } \\
\hline Māori & 5654 & 58.0 & 25.0 to 95.5 & $<0.001$ & 5614 & 57.7 & 25.2 to 93.9 & $<0.001$ \\
\hline Pacific & 3220 & 57.7 & 25.0 to 99.3 & $<0.001$ & 2510 & 57.5 & 25.2 to 97.1 & $<0.001$ \\
\hline Non-Māori/non-Pacific & 28244 & 72.1 & 25.0 to 105.9 & & 29605 & 69.3 & 25.0 to 102.9 & \\
\hline \multicolumn{9}{|l|}{ Age at death } \\
\hline Māori & 2003 & 66.3 & 29.1 to 96.7 & $<0.001$ & 2220 & 64.5 & 25.3 to 95.4 & $<0.001$ \\
\hline Pacific & 578 & 69.4 & 32.6 to 99.5 & $<0.001$ & 621 & 66.5 & 25.9 to 97.2 & $<0.001$ \\
\hline Non-Māori/non-Pacific & 11400 & 79.8 & 27.9 to 108.5 & & 12473 & 76.3 & 26.0 to 105.1 & \\
\hline \multicolumn{9}{|l|}{ Length of follow up } \\
\hline Māori & 5654 & 3.1 & 0 to 14 & $<0.001$ & 5614 & 2.9 & 0 to 14 & $<0.001$ \\
\hline Pacific & 3220 & 3.2 & 0 to 14 & $<0.001$ & 2510 & 2.7 & 0 to 14 & $<0.001$ \\
\hline Non-Māori/non-Pacific & 28244 & 2.7 & 0 to 14 & & 29605 & 2.6 & 0 to 14 & \\
\hline
\end{tabular}

(NZHIS). Follow up was from the date of the diabetes admission until the earlier of either date of death or 31 December 2001, the date for which cause of death data were available at the time of linkage. The underlying cause of death was used for all analyses.

\section{Statistical methods}

SMRs were calculated by comparing the mortality rate among patients with diabetes to the sex and ethnic specific mortality rates of the New Zealand population. The rates used for comparison were split by five year age bands and two year calendar periods. Analysis was performed using the PC life table analysis system. ${ }^{13}$ All reported p values are two sided.

\section{RESULTS}

Between February 1988 and December 2001, 76684 people were discharged from hospital with a code for type 2 diabetes on their discharge summary (see above for clarification). The following exclusions were made: not New Zealand residents $(\mathrm{n}=1664,2.2 \%)$, unknown sex $(\mathrm{n}=3,<0.1 \%)$, apparently died before diabetes diagnosis $(n=11,<0.1 \%)$, and missing date of death $(\mathrm{n}=159,0.2 \%)$. All analyses are based on 74847 people (37 118 women and 37729 men). These people were followed up for a maximum of 13 years. By the end of 2001, 29295 (39.1\%) cohort members had died.

Table 1 shows the characteristics of the study participants. The median age at index discharge was about 13 years lower for Māori and Pacific people compared with non-Maori/nonPacific people. The gap in median age at death between the ethnic groups was a correspondingly wide, although Pacific people, who were, on average, slightly younger than Māori at index diagnosis, were older at death than Māori.

The all cause SMR for all patients combined was 3.02 (95\% confidence intervals (CI): 2.99 to 3.06). Significantly raised SMRs were found for all major causes of death, including all cancers combined (2.40, 95\% CI: 2.34 to 2.47$)$, diseases of the circulatory $(2.82,95 \% \mathrm{CI}: 2.77$ to 2.87$)$, respiratory $(1.97,95 \%$ CI: 1.89 to 2.06$)$, digestive $(3.05,95 \%$ CI: 2.85 to 3.26$)$, and genitourinary $(3.31,95 \% \mathrm{CI}: 3.04$ to 3.60$)$ systems, as well as external causes (1.99, 95\% CI: 1.81 to 2.19$)$. Site specific cancer analyses showed that the sites at which diabetic patients were most at risk, with an SMR exceeding 3.0, were liver, gallbladder, pancreas, oro-pharynx, brain and nervous system, and non-thyroid endocrine glands. However, significantly raised SMRs $(\mathrm{p}<0.01)$ were evident for almost all sites, including important sites of non-smoking related

Table 2 Cause specific standardised mortality ratios among 37118 women hospitalised for diabetes, New Zealand, 1988 to 2001

\begin{tabular}{|c|c|c|c|c|c|c|c|c|c|}
\hline \multirow[b]{2}{*}{ Cause of death (ICD-9) } & \multicolumn{3}{|c|}{ Maori ( $n=5654$ ) } & \multicolumn{3}{|c|}{ Pacific $(n=3220)$} & \multicolumn{3}{|c|}{ Other $(n=28244)$} \\
\hline & Deaths & SMR & $95 \% \mathrm{Cl}$ & Deaths & SMR & $95 \% \mathrm{Cl}$ & Deaths & SMR & $95 \% \mathrm{Cl}$ \\
\hline All deaths & 2003 & 3.80 & $3.64,3.97$ & 578 & 2.41 & $2.21,2.61$ & 11400 & 2.98 & $2.93,3.04$ \\
\hline $\begin{array}{l}\text { Infectious and parasitic diseases } \\
(001-139)\end{array}$ & 15 & 3.17 & $1.77,5.23$ & 9 & 3.30 & $1.51,6.26$ & 55 & 3.42 & $2.57,4.45$ \\
\hline All cancers (150-208) & 433 & 2.85 & $2.59,3.14$ & 119 & 1.81 & $1.50,2.17$ & 2032 & 2.59 & $2.48,2.71$ \\
\hline $\begin{array}{l}\text { Endocrine, nutritional, and } \\
\text { metabolic (240-259, 270-279) }\end{array}$ & 524 & 11.36 & $10.41,12.37$ & 166 & 5.81 & $4.96,6.77$ & 1797 & 18.49 & $17.65,19.37$ \\
\hline Mental disorders (290-319) & 6 & 1.32 & $0.48,2.88$ & 6 & 1.65 & $0.60,3.60$ & 188 & 1.39 & $1.20,1.61$ \\
\hline $\begin{array}{l}\text { Diseases of nervous system } \\
(320-359)\end{array}$ & 11 & 3.58 & $1.79,6.41$ & 3 & 1.19 & $0.25,3.49$ & 114 & 1.38 & $1.14,1.65$ \\
\hline Diseases of circulatory system & 665 & 3.03 & $2.81,3.27$ & 192 & 1.88 & $1.62,2.17$ & 5263 & 2.74 & $2.66,2.81$ \\
\hline $\begin{array}{l}\text { Diseases the respiratory system } \\
(460-519)\end{array}$ & 126 & 2.17 & $1.81,2.59$ & 26 & 1.50 & $0.98,2.19$ & 837 & 2.02 & $1.88,2.16$ \\
\hline $\begin{array}{l}\text { Diseases of digestive system } \\
(520-579)\end{array}$ & 52 & 4.39 & $3.28,5.75$ & 11 & 1.71 & $0.85,3.06$ & 371 & 2.83 & $2.55,3.14$ \\
\hline $\begin{array}{l}\text { Diseases of genitourinary } \\
\text { system (580-629) }\end{array}$ & 55 & 5.87 & $4.42,7.64$ & 11 & 2.86 & $1.43,5.12$ & 223 & 3.45 & $3.02,3.94$ \\
\hline $\begin{array}{l}\text { Diseases of skin and } \\
\text { subcutaneous tissue (680-709) }\end{array}$ & 6 & 3.71 & $1.36,8.08$ & 3 & 3.48 & $0.72,10.18$ & 21 & 2.05 & $1.27,3.13$ \\
\hline $\begin{array}{l}\text { Diseases of musculoskeletal } \\
\text { system and connective } \\
\text { tissue (710-739) }\end{array}$ & 9 & 4.57 & $2.09,8.68$ & 1 & 1.22 & $0.03,6.76$ & 72 & 1.95 & $1.53,2.46$ \\
\hline External causes (E800-E999) & 17 & 1.96 & $1.14,3.14$ & 2 & 0.69 & $0.08,2.50$ & 178 & 2.19 & $1.88,2.53$ \\
\hline
\end{tabular}


Table 3 Cause specific standardised mortality ratios among 37729 men hospitalised for diabetes, New Zealand, 1988 to 2001

\begin{tabular}{|c|c|c|c|c|c|c|c|c|c|}
\hline \multirow[b]{2}{*}{ Cause of death (ICD-9) } & \multicolumn{3}{|c|}{ Maori $(n=5614)$} & \multicolumn{3}{|c|}{ Pacific $(n=2510)$} & \multicolumn{3}{|c|}{ Other $(n=29605)$} \\
\hline & Deaths & SMR & $95 \% \mathrm{Cl}$ & Deaths & SMR & $95 \% \mathrm{Cl}$ & Deaths & SMR & $95 \% \mathrm{Cl}$ \\
\hline All deaths & 2220 & 3.44 & $3.30,3.58$ & 621 & 2.23 & $2.06,2.41$ & 12473 & 2.99 & $2.93,3.04$ \\
\hline $\begin{array}{l}\text { Infectious and parasitic } \\
\text { diseases }(001-139)\end{array}$ & 22 & 3.76 & $2.36,5.70$ & 14 & 4.18 & $2.28,7.01$ & 65 & 3.48 & $2.69,4.43$ \\
\hline All cancers (150-208) & 414 & 2.26 & $2.05,2.49$ & 138 & 1.75 & $1.47,2.07$ & 2628 & 2.31 & $2.22,2.40$ \\
\hline $\begin{array}{l}\text { Endocrine, nutritional and } \\
\text { metabolic }(240-259,270-279)\end{array}$ & 585 & 10.42 & $9.59,11.30$ & 148 & 6.21 & $5.25,7.30$ & 1864 & 17.45 & $16.66,18.26$ \\
\hline Mental disorders (290-319) & 6 & 1.32 & $0.48,2.87$ & 1 & 0.35 & $0.01,1.95$ & 144 & 1.82 & $1.54,2.15$ \\
\hline $\begin{array}{l}\text { Diseases of nervous system } \\
(320-359)\end{array}$ & 11 & 2.80 & $1.40,5.01$ & 4 & 1.54 & $0.42,3.94$ & 134 & 1.63 & $1.37,1.93$ \\
\hline Diseases of circulatory system & 860 & 3.08 & $2.87,3.29$ & 225 & 1.99 & $1.73,2.26$ & 5615 & 2.94 & $2.86,3.02$ \\
\hline $\begin{array}{l}\text { Diseases the respiratory system } \\
(460-519)\end{array}$ & 113 & 1.91 & $1.57,2.29$ & 39 & 1.32 & $0.94,1.80$ & 987 & 1.98 & $1.85,2.10$ \\
\hline $\begin{array}{l}\text { Diseases of digestive system } \\
(520-579)\end{array}$ & 55 & 3.78 & $2.85,4.92$ & 14 & 1.45 & $0.79,2.43$ & 357 & 3.29 & $2.96,3.65$ \\
\hline $\begin{array}{l}\text { Diseases of genitourinary } \\
\text { system (580-629) }\end{array}$ & 40 & 3.51 & $2.51,4.78$ & 6 & 1.14 & $0.42,2.49$ & 215 & 2.99 & $2.61,3.42$ \\
\hline $\begin{array}{l}\text { Diseases of skin and } \\
\text { subcutaneous tissue (680-709) }\end{array}$ & 7 & 6.56 & $2.63,13.52$ & 2 & 2.56 & $0.31,9.24$ & 25 & 4.22 & $2.73,6.24$ \\
\hline $\begin{array}{l}\text { Diseases of musculoskeletal } \\
\text { system and connective tissue } \\
\text { (710-739) }\end{array}$ & 5 & 2.58 & $0.84,6.03$ & 0 & - & & 49 & 2.75 & $2.04,3.64$ \\
\hline External causes (E800-E999) & 38 & 1.92 & $1.36,2.63$ & 10 & 2.07 & $0.99,3.81$ & 185 & 1.88 & $1.62,2.17$ \\
\hline
\end{tabular}

cancers such as colorectal, breast, prostate, urinary, and haematopoietic system.

Sex and ethnic specific SMRs for the major categories of cause of death and also for specific subcategories of particular interest are shown in table 2 (women) and table 3 (men). SMRs, comparing the mortality experience among people hospitalised for diabetes to the general population of the same ethnicity, differed across the three ethnic groups. The lowest excess mortality was in Pacific people, intermediate in the non-Māori/non-Pacific group, and the highest SMRs in Māori, both women and men.

Mortality patterns differed by cause, with the highest SMRs seen for endocrine and metabolic disorders, reflecting the use of a code for diabetes mellitus on the death certificate. Mortality from cardiovascular disease was particularly high in the population with diabetes compared with the general population, with differing patterns by ethnicity, but similar SMRs in women and men. There was roughly equal contribution to this raised SMR from ischaemic heart and cerebrovascular disease (results not shown).

The significantly raised SMRs for diseases of the nervous, respiratory and musculoskeletal systems, and diseases of the skin and subcutaneous tissue and mental disorders show that the mortality patterns that we see are comparatively nonspecific. The excess mortality from external causes differed by ethnicity. Among Māori, the raised SMRs were equally attributable to transport related accidents (ICD-9: 800 to 848 ) and other accidents (880 to 929), whereas in the nonMāori/non-Pacific group, the greatest contribution to the excess death from external causes was other accidents. SMRs for suicide were significantly raised for non-Māori/nonPacific, but not for Māori people with diabetes. The few deaths from external causes among Pacific people $(n=12)$ precluded further interpretation of these results.

Excess mortality from cancer was evident in each ethnic group and both sexes. In addition to raised SMRs for pancreatic cancer, mortality was high for both smoking related and non-smoking related cancers. Table 4 shows further details of these associations. Unlike for cardiovascular diseases, the excess mortality seemed to be similar across the ethnic groups for many of the sites at which the SMRs were raised.

\section{DISCUSSION}

The findings from our study are in agreement with a number of previous studies, showing increased risks of all cause and cardiovascular disease mortality in a cohort of patients discharged from hospital with diabetes. Because of the large size of the cohort, we were also able to explore cause specific mortality, which was found to be raised in comparison with the general population for most causes of death. Importantly, we found that the pattern of excess mortality, although broadly similar across ethnic groups, was substantially higher in Māori and lower in Pacific people compared with nonMāori/non-Pacific people for cardiovascular disease, the single greatest contributor to the excess mortality in patients with diabetes.

The study was based only a cohort of diabetes patients who were hospitalised, thus including those patients with more severe disease than a community based sample.

This raises the potential for reverse causality, as we are unable to determine either the temporality of the onset of diabetes and other comorbidities that could underlie the cause of death. This issue may be particularly important for the results for cancer mortality, as cancer treatments could lead to diabetes. Nor could we exclude the possibility of detection bias, as patients could have been admitted to hospital for a reason related to their cause of death, and had diabetes diagnosed for the first time in hospital, thus creating a spurious association between diabetes and mortality.

Because of the completeness of the data in the NMDS, we restricted our analyses to discharges from public hospitals, at which access to care is free. We estimate that about $2 \%$ of all diagnoses of diabetes may have been omitted from our analyses through the omission of private hospital diagnoses. It is unlikely that this will have had a large impact on our results. We chose to use a cut off of age 25 years at hospital discharge to define adult onset disease. This is likely to be reasonably reliable in the later years of the data, because someone who was discharged from hospital for the first time and had not been discharged in the previous 10 years is likely to have been comparatively recently diagnosed. However, for the earlier years of the data, we are likely to have included a proportion of patients with type 1 diabetes, if they had been incorrectly coded as type 2 instead of type 1. This could 
Table 4 Cancer site specific standardised mortality ratios among 74847 people hospitalised for diabetes, New Zealand, 1988 to 2001

\begin{tabular}{|c|c|c|c|c|c|c|c|c|c|}
\hline \multirow[b]{2}{*}{ Cause of death ICD-9 } & \multicolumn{3}{|c|}{ Maori ( $n=11268$ ) } & \multicolumn{3}{|c|}{ Pacific $(n=5730)$} & \multicolumn{3}{|c|}{ Other $(n=57849)$} \\
\hline & Deaths & SMR & $95 \% \mathrm{Cl}$ & Deaths & SMR & $95 \% \mathrm{Cl}$ & Deaths & SMR & $95 \% \mathrm{Cl}$ \\
\hline \multicolumn{10}{|l|}{ Lip, oro-pharynx } \\
\hline women & 3 & 3.46 & $0.71,10.13$ & 0 & - & & 20 & 2.32 & $1.41,3.58$ \\
\hline men & 2 & 0.57 & $0.07,2.06$ & 2 & 0.88 & $0.11,3.17$ & 33 & 1.91 & $1.32,2.69$ \\
\hline \multicolumn{10}{|l|}{ Oesophagus } \\
\hline women & 4 & 2.13 & $0.58,5.45$ & 1 & 5.66 & $0.14,31.44$ & 29 & 1.48 & $0.99,2.13$ \\
\hline men & 4 & 0.63 & $0.17,1.61$ & 3 & 3.64 & $0.75,10.64$ & 71 & 1.97 & $1.54,2.48$ \\
\hline \multicolumn{10}{|l|}{ Stomach } \\
\hline women & 25 & 3.10 & $2.01,4.58$ & 10 & 2.38 & $1.14,4.38$ & 54 & 1.88 & $1.42,2.46$ \\
\hline men & 39 & 2.91 & $2.07,3.98$ & 4 & 0.59 & $0.16,1.52$ & 108 & 2.19 & $1.79,2.64$ \\
\hline \multicolumn{10}{|l|}{ Colon } \\
\hline women & 5 & 1.10 & $0.36,2.57$ & 3 & 1.45 & $0.30,4.24$ & 195 & 1.89 & $1.63,2.17$ \\
\hline men & 17 & 2.27 & $1.32,3.63$ & 3 & 1.01 & $0.21,2.96$ & 233 & 2.21 & $1.94,2.52$ \\
\hline \multicolumn{10}{|l|}{ Rectum } \\
\hline women & 7 & 1.60 & $0.64,3.30$ & 5 & 2.75 & $0.89,6.41$ & 89 & 2.24 & $1.80,2.76$ \\
\hline men & 15 & 2.09 & $1.17,3.44$ & 7 & 2.67 & $1.07,5.51$ & 132 & 2.08 & $1.74,2.47$ \\
\hline \multicolumn{10}{|l|}{ Liver } \\
\hline women & 12 & 5.78 & $2.98,10.09$ & 3 & 1.21 & $0.25,3.54$ & 36 & 4.29 & $3.01,5.94$ \\
\hline men & 33 & 3.55 & $2.44,4.98$ & 9 & 1.80 & $0.82,3.41$ & 79 & 5.45 & $4.31,6.79$ \\
\hline \multicolumn{10}{|l|}{ Pancreas } \\
\hline women & 32 & 4.88 & $3.34,6.89$ & 4 & 2.29 & $0.62,5.86$ & 173 & 4.60 & $3.94,5.34$ \\
\hline men & 25 & 3.40 & $2.20,5.02$ & 6 & 2.17 & $0.79,4.72$ & 197 & 4.75 & $4.11,5.46$ \\
\hline \multicolumn{10}{|l|}{ Lung } \\
\hline women & 150 & 2.70 & $2.29,3.17$ & 18 & 1.62 & $0.96,2.56$ & 273 & 2.69 & $2.38,3.03$ \\
\hline men & 138 & 2.09 & $1.76,2.47$ & 38 & 1.64 & $1.16,2.25$ & 552 & 2.26 & $2.08,2.46$ \\
\hline \multicolumn{10}{|l|}{ Melanoma } \\
\hline women & 2 & 2.43 & $0.29,8.77$ & 1 & 7.46 & $0.19,41.46$ & 39 & 2.24 & $1.59,3.06$ \\
\hline men & 0 & - & & 0 & - & & 66 & 2.01 & $1.56,2.56$ \\
\hline \multicolumn{10}{|l|}{ Breast } \\
\hline women & 41 & 1.98 & $1.42,2.69$ & 14 & 1.28 & $0.70,2.14$ & 298 & 2.60 & $2.31,2.91$ \\
\hline \multicolumn{10}{|l|}{ Prostate } \\
\hline \multicolumn{9}{|l|}{ Bladder } & $1.61,1.99$ \\
\hline women & 3 & 1.99 & $0.41,5.82$ & 0 & - & & 40 & 2.34 & $1.67,3.19$ \\
\hline men & 3 & 1.64 & $0.34,4.80$ & 3 & 2.54 & $0.52,7.44$ & 100 & 2.51 & $2.04,3.05$ \\
\hline \multicolumn{10}{|l|}{ Kidney } \\
\hline women & 6 & 4.15 & $1.52,9.03$ & 0 & - & & 45 & 3.17 & $2.31,4.24$ \\
\hline men & 14 & 4.14 & $2.26,6.94$ & 3 & 2.56 & $0.53,7.48$ & 65 & 2.67 & $2.06,3.40$ \\
\hline \multicolumn{10}{|l|}{ Brain } \\
\hline women & 3 & 2.27 & $0.47,6.64$ & 2 & 1.31 & $0.16,4.74$ & 50 & 3.54 & $2.63,4.66$ \\
\hline men & 4 & 2.04 & $0.56,5.23$ & 2 & 2.51 & $0.30,9.05$ & 62 & 2.93 & $2.25,3.76$ \\
\hline Non-Hodgkin's lymphon & & & & & & & & & \\
\hline women & 10 & 2.59 & $1.24,4.76$ & 8 & 2.63 & $1.13,5.17$ & 85 & 2.74 & $2.19,3.38$ \\
\hline men & 9 & 2.24 & $1.02,4.26$ & 7 & 2.30 & $0.92,4.73$ & 112 & 2.86 & $2.35,3.44$ \\
\hline Multiple myeloma & & & & & & & & & \\
\hline women & 7 & 2.92 & $1.17,6.02$ & 5 & 2.73 & $0.88,6.37$ & 38 & 2.35 & $1.66,3.23$ \\
\hline men & 17 & 4.20 & $2.44,6.72$ & 3 & 1.25 & $0.26,3.67$ & 42 & 2.00 & $1.44,2.70$ \\
\hline Lymphoid leukaemia & & & & & & & & & \\
\hline women & 4 & 4.03 & $1.10,10.31$ & 0 & - & & 24 & 2.87 & $1.84,4.27$ \\
\hline men & 7 & 4.91 & $1.97,10.12$ & 0 & - & & 34 & 2.57 & $1.78,2.59$ \\
\hline Myeloid leukaemia & & & & & & & & & \\
\hline women & 5 & 2.38 & $0.77,5.57$ & 2 & 1.38 & $0.17,4.99$ & 44 & 3.28 & $2.38,4.40$ \\
\hline men & 3 & 1.40 & $0.29,4.10$ & 3 & 1.85 & $0.38,5.41$ & 49 & 2.26 & $1.68,2.99$ \\
\hline
\end{tabular}

explain the comparatively high all cause SMR that we report in comparison with other studies, as SMRs tend to be higher for type 1 than type 2 diabetes. ${ }^{4}$

Although the recording of diabetes on death certificates of people with diabetes is notoriously low, both in New Zealand ${ }^{14}$ and internationally, this will not affect the results that we present for cardiovascular disease or cancer, because there is no reason to think that these causes of disease are differentially underreported in patients with and without diabetes. Similarly, although the high prevalence of undiagnosed patients with suspected diabetes in New Zealand is high, ${ }^{15}$ this should not affect the results from the sample on which the analysis is based.

Previous studies of mortality among diabetic patients have found similar results to ours, with excess mortality from all causes, cardiovascular disease, and renal disease evident in most reports. ${ }^{16-8}$ The evidence for the presence of a positive association between diabetes and cancer mortality is less consistent. Many studies have shown that patients with diabetes are at a higher risk of $\operatorname{liver}^{8}$ and pancreatic cancer, ${ }^{16}{ }^{17}$ with SMRs of over threefold commonly reported. There is less consistency in the reported associations between cancer mortality in populations with type 2 diabetes compared with the general population. Several of the cohort studies that have failed to find an association between diabetes and all cancer mortality include a very small number of cases, such as a follow up of the NHANES-1 survey (486 deaths among patients with diabetes $)^{18}$ the Whitehall cohort of men ( 188 deaths $)^{17}$ compared with over 2500 in our study. A Swedish study of similar design to ours reported an SMR of 1.46 (95\% CI: 1.40, 1.52) in their group of hospitalised patients who had "probably NIDDM". A SMR of similar magnitude was found in the probable IDDM group.

Associations between diabetes and cause specific mortality may be evident because of shared common risk factors (for example, smoking) or an influence of lack of glycaemic 


\section{What this paper adds}

- A pattern of high mortality rates from cardiovascular disease, renal disease, and cancer was found in hospitalised patients with diabetes compared with the general population.

- These SMRs were particularly high for Māori, the indigenous population of New Zealand, but not for Pacific people living in New Zealand.

- The results suggest that Māori admitted to hospital with diabetes may have more severe disease that nonMāori, which could be attributable to differential access to primary care for Māori with diabetes.

control on vascular or other tissues. It is probable that associations between smoking related cancers and diabetes may be attributable to the common cause of smoking in these cancers and the development of diabetes. ${ }^{19}{ }^{20}$ However, such obvious confounding is less clear for non-smoking related cancers.

There is accumulating evidence that colorectal cancer risk is higher in patients with diabetes, and in particular this increased risk may be related to glycaemic control. ${ }^{21}$ Such findings shed important light on the role of the insulin/ insulin-like growth factor (IGF) axis in the development of or survival from these cancers. One of the symptoms of insulin resistance is high levels of circulating insulin, which are related to increased bioactivity of IGF-I, as well as to its bioavailability through the association with IGF binding proteins. ${ }^{22}{ }^{23}$ Hyperinsulinaemia has been related to several hormone responsive cancers, ${ }^{24}$ particularly of the colorectum, endometrium, and breast. $^{25}$ Several previous studies (reviewed in Rodriguez et $\mathrm{al}^{26}$ ) have shown lower risks of prostate cancer in patients with diabetes compared with the general population. We have found moderately raised SMRs for prostate cancer, consistent with the suggestion that high insulin levels present during insulin resistance and the early phase of diabetes are associated with prostate cancer risk. It has been proposed that the relation between diabetes and prostate cancer is modified by duration of diabetes, with higher risks of prostate cancer in the early years after a diabetes diagnosis reducing to lower risks in later years. ${ }^{26}{ }^{27}$ Given the decades during which prostate cancer develops, these data suggest that raised insulin levels may act as a promoter of prostate cancer, rather than having a carcinogenic effect in itself.

Some studies have reported sex differences in the mortality experiences of diabetic patients. However, most larger studies, such as NHANES ${ }^{18}$ and the Swedish linkage study ${ }^{4}$ found no evidence to suggest sex differences in mortality among diabetics. In this study, most off the site specific SMRs are similar in women and men. An important finding in this study was the high SMR among Māori for cardiovascular disease compared with the other ethnic groups. This is likely to reflect poorer glycaemic control and hence more severe macro-vascular complications among Māori, who are known to be medically underserved in New Zealand according to their need. ${ }^{28}$

The results for Pacific people in these data are intriguing, with SMRs, particularly those for cancer and cardiovascular disease, consistently lower that the Māori or non-Māori/nonPacific group. Through the inclusion only of New Zealand residents, we have minimised the risk to including patients from the Pacific who come to New Zealand for treatment. Although we cannot rule out the possibility of selective emigration of sick people, this is not thought to account for the mortality patterns seen in Pacific people in New Zealand (C Wright, personal communication, 2004). Although lower mortality among Hispanic people in America has been described, this "Hispanic-paradox" has not been replicated in studies of diabetes, with Mexican Americans born in the USA experiencing higher mortality rates than non-Hispanic white people. ${ }^{29}$

In summary, we have reported high SMRs for several causes of death in a cohort of patients admitted to hospital for diabetes. The findings with respect to cancer add to our understanding of the aetiology of non-smoking related cancers. The pattern of excess mortality by ethnicity should be further investigated, as this may be amenable to intervention to improve outcomes for Māori.

\section{Authors' affiliations}

M Jeffreys, A't Mannetie, K Huang, N Pearce, Centre for Public Health Research, Massey University, Wellington, New Zealand

C Wright, K Huang, Public Health Intelligence, Ministry of Health, Wellington, New Zealand

Funding: the Centre for Public Health Research is supported by a program grant from the Health Research Council of New Zealand.

Competing interests: none declared.

\section{REFERENCES}

1 Moss SE, Klein R, Klein BE. Cause-specific mortality in a population-based study of diabetes. Am J Public Health 1991;81:1158-62.

2 Kleinman JC, Donahue RP, Harris MI, et al. Mortality among diabetics in a national sample. Am J Epidemiol 1988;128:389-401

3 Swerdlow AJ, Jones ME. Mortality during 25 years of follow-up of a cohort with diabetes. Int J Epidemiol 1996;25:1250-61.

4 Weiderpass E, Gridley G, Nyren O, et al. Cause-specific mortality in a cohort of patients with diabetes mellitus: a population-based study in Sweden. J Clin Epidemiol 2001;54:802-9.

5 Brown L, Scott RS, Moir CL. All-cause mortality in the Canterbury (New Zealand) insulin-treated Diabetic Registry population. Diabetes Care 2001;24:56-63.

6 Morgan CL, Currie CJ, Peters JR. Relationship between diabetes and mortality: a population study using record linkage. Diabetes Care 2000;23:1 103-7.

7 de Marco R, Locatelli F, Zoppini G, et al. Cause-specific mortality in type 2 diabetes. The Verona diabetes study. Diabetes Care 1999;22:756-61.

8 Sasaki A, Horiuchi N, Hasegawa K, et al. Mortality and causes of death in type 2 diabetic patients. A long-term follow-up study in Osaka District, Japan. Diabetes Res Clin Pract 1989;7:33-40.

9 Florkowski CM, Scott RS, Graham PJ, et al. Cause-specific and total mortality in the Canterbury (New Zealand) insulin-treated Diabetic Registry population: a 15-year follow-up study. Diabet Med 2003;20:191-7.

10 Diabetes New Zealand. Fact sheet 1.1: Key facts about diabetes, 2002. http://www.diabetes.org.nz.

11 Public Health Intelligence. Modelling diabetes: a summary. Wellington: Public Health Intelligence occasional bulletin no 11, 2002.

12 Department of statistics. Ethnicity in New Zealand: recommendations for a standard classification. Wellington: Department of Statistics, 1990.

13 Cassinelli R, Kock K, Steenland K, et al. User documentation PC LTAS: life table analysis system for use on the PC. http://www.cdc.gov/niosh/ ltindex.html.

14 Coppell K, McBride K, Williams S. Under-reporting of diabetes on death certificates among a population with diabetes in Otago Province, New Zealand. N Z Med J 2004;117:U1217.

15 Ellison TL, Elliott R, Moyes SA. HbAlc screening for undiagnosed diabetes in New Zealand. Diabetes Metab Res Rev 2005;21:65-70.

16 Kessler I. Cancer mortality among diabetics. J Natl Cancer Inst 1970;44:673-86.

17 Batty D, Shipley M, Marmot M, et al. Diabetes status and post-load plasma glucose concentration in relation to site-specific cancer mortality: findings from the original Whitehall study. Cancer Causes Control 2004;15:873-81.

18 Gu K, Cowie CC, Harris MI. Mortality in adults with and without diabetes in a national cohort of the US population, 1971-1993. Diabetes Care 1998;21:1138-45.

19 Sairenchi T, Iso H, Nishimura A, et al. Cigarette smoking and risk of type 2 diabetes mellitus among middle-aged and elderly Japanese men and women. Am J Epidemiol 2004;160:158-62.

20 Rimm EB, Chan J, Stampfer MJ, et al. Prospective study of cigarette smoking, alcohol use, and the risk of diabetes in men. BMJ 1995;310:555-9.

21 Renehan AG, Shalet SM. Diabetes, insulin therapy, and colorectal cancer. BMJ 2005;330:551-2.

22 Stoll B. Timing of weight gain in relation to breast cancer risk. Ann Oncol 1995;6:245-8.

23 Leifke E, Gorenoi V, Wichers C, et al. Age-related changes of serum sex hormones, insulin-like growth factor-1 and sex-hormone binding globulin 
levels in men: cross-sectional data from a healthy male cohort. Clin Endocrinol (Oxf) 2000;53:689-95

24 Kaaks R. Insulin, insulin-like growth factor-I (IGF-I) and cancer. Biotech Medecine 2002; 23:http://www. biotech-medecine.com/archives/review23.

25 Lawlor DA, Smith GD, Ebrahim S. Hyperinsulinaemia and increased risk of breast cancer: findings from the British women's heart and health study. Cancer Causes Control 2004; 15:267-75.

26 Rodriguez C, Patel AV, Mondul AM, et al. Diabetes and risk of prostate cancer in a prospective cohort of US men. Am J Epidemiol 2005; 161:147-52
27 Giovannucci E, Rimm EB, Stampfer MJ, et al. Diabetes mellitus and risk of prostate cancer (United States). Cancer Causes Control 1998;9:3-9.

28 Malcolm L. Inequities in access to and utilisation of primary medical care services for Maori and low income New Zealanders. N Z Med J 1996:109.356-8

29 Hunt KJ, Williams K, Resendez RG, et al. All-cause and cardiovascular mortality among diabetic participants in the San Antonio heart study: evidence against the "Hispanic paradox". Diabetes Care 2002; 25:1557-63.

\section{THE JECH GALLERY}

Sir John Pringle's Observations on the Diseases of the Army-an early scientific account of epidemiology and the prevention of cross infection

orn in 1707, Pringle studied medicine at Leiden and Paris before practising in Edinburgh. In 1744 he became physician general to the British army and he was present at the battle of Culloden. In 1752 the first of the many editions of Pringle's Diseases of the Army was published. In the volume Pringle identified hospitals as a major cause of sickness and began to think in terms of septic and antiseptic. Pringle felt that fevers, dysentery, and jail fever were the three most prevalent and fatal diseases affecting armies and although he was wrong about the way they were transmitted (he blamed putrid air) his recommendations for prevention helped to control epidemics. After his retiral from the army Pringle started a successful London practice. He was a president of the Royal Society and physician-in-ordinary to the king. Sir John died in 1782.

\section{FURTHER READING}

- Pringle J. Observations on the diseases of the army in camp and garrison. London: Millar, Wilson and Payne, 1752.

- Kippis A. The life of Sir John Pringle. In: Six discourses delivered by Sir John Pringle. London: Strahan and Cadell, 1783.

- Pringle's historic manuscripts on display http://news.bbc.co.uk/l/hi/scotland/ 4007407.stm

I Milne Library and Information Services, Royal College of Physicians of Edinburgh, 9 Queen Street, Edinburgh EH2 IJQ, UK; i.milne@rcpe.ac.uk

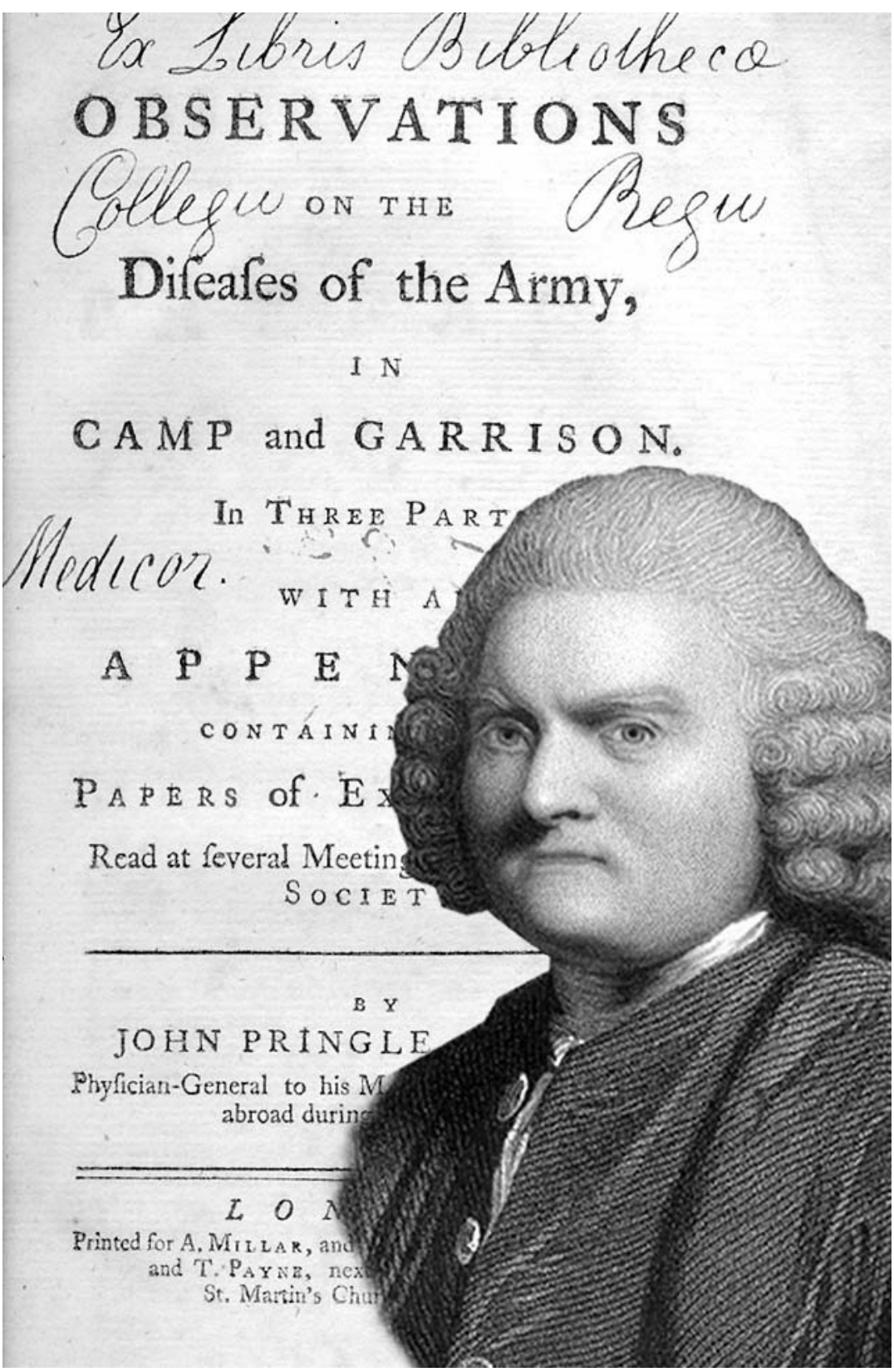

Illustration courtesy of the Royal College of Physicians of Edinburgh. 